\title{
IMPACT OF DIFFERENT PACKAGING SYSTEMS ON SELECTED ANTIOXIDANT PROPERTIES OF FROZEN-STORED BROCCOLI
}

\author{
WPŁYW RÓŻNEGO RODZAJU OPAKOWAŃ NA WYBRANE WŁAŚCIWOŚCI \\ ANTYOKSYDACYJNE BROKULA SKŁADOWANEGO \\ W STANIE ZAMROŻENIA
}

\begin{abstract}
Broccoli has a very good nutritive value, high antioxidant activity and pro-healthy potential. Freezing is one of best methods for vegetable storage and broccoli belongs to the group of vegetables subjected to this process on an industrial scale. This work investigates the effect of type of container: low density polyethylene (PE-LD) bags and oriented polystyrene (OPS) boxes on selected quality parameters in frozen broccoli. The experimental material was the broccoli cultivar Lord $_{F 1}$. The vegetable was subjected to blanching, freezing and 3-month storage. At the every stage of an experiment the material was examined in terms of: vitamin $\mathrm{C}$ content; $\beta$-carotene; total polyphenols; and antioxidant potential, which was determined basing on the ability to quench the $\mathrm{ABTS}^{++}$free radical. It has been found that vegetables which were kept frozen for 3 months in two types of container had parallel levels of vitamin C, $\beta$-carotene; total polyphenols; and similar antioxidative potential.
\end{abstract}

Keywords: antioxidant activity, $\beta$-carotene, broccoli, frozen-stored, total polyphenols, vitamin C

\section{Introduction}

Brassicaceae (Brassicas earlier known as Cruciferae) is a plant family of a great economic significance, which comprises about 340 genera and 3700 species. Their major advantage is low costs of cultivation along with almost whole-year availability, particularly in periods characterized by a shortage of fresh vegetables. Therefore, they are recognized to be a crucial element in chemoprevention of cancer [1-3].

The oxidative stress is an important mechanism in pathophysiology of several diseases. Nature has bestowed the human body with a complex web of antioxidant defense system including enzymatic antioxidants (glutathione peroxidase, glutathione reductase, catalase and superoxide dismutase) as well as non-enzymatic antioxidants (thiol antioxidants, melatonin, coenzyme Q, and metal chelating proteins), which are efficient enough to fight against excessive free radicals. Also, nutrient antioxidants such as vitamin $\mathrm{C}$, vitamin $\mathrm{E}$, carotenoids, polyphenols or trace elements are known to have high antioxidant potential to

\footnotetext{
${ }^{1}$ University of Agriculture in Krakow, ul. Balicka 122, 30-149 Kraków, Poland, phone +48 126624816 , fax +48126624812

*Corresponding author: joannakapustaduch@interia.pl
} 
assist in minimizing harmful effects of reactive species. Antioxidants protect plants against unfavourable environmental factors and enhance their ability to adapt to varying environmental conditions through, among other, increased synthesis of polyphenols. Provided in a daily diet to the human organism they inhibit ageing and reduce the risk of several diseases [4].

Brassicas contain numerous biologically active substances such as, i.a., vitamins $\mathrm{C}$ and E, carotenoids, polyphenols, and glucosinolates, presence of which determine their anti-inflammatory and antimutagenic properties and affect expression of gene responsible for cell proliferation in the development of cancer through modulation of cell redox homeostasis $[3,5,6]$. Some of polyphenol groups show anti-inflammatory, anti-allergic, anti-clotting, anti-virus, and anti-cancerogenic properties [7, 8].

Vitamin $\mathrm{C}$ is an essential nutrient with important antioxidant properties. In the organism, vitamin $\mathrm{C}$ is a fundamental element of the defence line against the oxidative stress. It normalizes superoxide dismutase and catalase gene expression and inhibits disulphur isomerase gene expression, the latter being responsible for the enhanced growth of vascular smooth muscles. In such cells, the vitamin reduces elastin content at the level of transcription. Moreover, vitamin $\mathrm{C}$ reduces expression of the adhesion molecules in monocytes; shows cytoprotective activity inducing $\mathrm{Bcl}-2$ gene expression; and in the case of patients suffering from hypertension and diabetes, improves function of endothelium in coronary vessels and the brachial artery $[9,10]$. Vitamin $\mathrm{C}$ is absorbed from the small intestine in humans, achieving peak plasma vitamin $\mathrm{C}$ concentrations approximately 120-180 minutes after ingestion. After absorption, because vitamin $\mathrm{C}$ is water soluble, it is distributed from blood throughout the extracellular space. A high vitamin $\mathrm{C}$ level in the consumed food can also contribute to enlarged excretion of cations with urine, including also heavy metals cations [11].

Carotenoids remain a fascinating group of natural pigments. Not only are they responsible for a broad array of coloration in nature, but, more importantly, they have key functional roles in biology. Carotenoids exhibit broad-spectrum antioxidant activity since they are classified to both preventive and interventional antioxidants. Beta-carotene is crucial for the following processes: the process of vision; formation of epithelium; tissue growth; maintaining stability of the epithelium cells; synthesis of adrenocortical hormones; tyrosine secretion from the thyroid gland; maintaining layers around a neuron in proper condition; immunological reactions; erythrocyte formation; and in cancer prevention since it inactivates free radicals through the transfer of electrons or forming adducts with them [12].

Glucosinolates are secondary plant metabolites found in the family Brassicaceae. Several epidemiological and pharmacological studies have demonstrated that dietary glucosinolates and their breakdown products may reduce the risk of carcinogenesis and particular human diseases. Glucosinolates are relatively biologically inert glucosides; however, their hydrolysis by myrosinase (b-thioglucosidase) enzymes after chopping vegetables, chewing of raw vegetables or insect attack leads to the conversion of biologically active compounds. Isothiocyanates and indoles are characterized by serious pro-health properties [13]. These substances can affect excretion or neutralization of carcinogenic or mutagenic factors through inducing enzyme systems from the phases I and II of xenobiotic metabolism and, consequently, inhibit DNA methylation and development of tumors. In the phase I, the products of GLS hydrolysis can activate or inhibit mono-oxygenases catalysing a number of redox processes; whereas, in the phase II of 
detoxification, in which associations are formed between xenobiotic metabolites and endogenous substances to excrete them from the organism, they can enhance transferase activity $[14,15]$.

The weakness of vegetables is their seasonal availability and fact that they are perishable. In view of the above, food technology is focused on discovering and establishing the methods of storage, which will least affect their chemical composition. Broccoli belongs to the group of vegetables subjected to freezing process on an industrial scale.

The aim of this work was to reveal changes in vitamin $C, \beta$-carotene, total polyphenols and antioxidant activity occurring in the cultivar Lord $_{F 1}$ of broccoli (Brassica oleracea L. var. italica) during blanching, freezing and frozen storage for the three successive months in two types of container: PE-LD bags with the zipper closure and sealed OPS food boxes. Overall, this study were undertaken to broaden knowledge on health-promoting properties of broccoli, particularly in terms of the following indicators: vitamin $\mathrm{C}, \beta$-carotene, total polyphenols and antioxidant activity. In addition, the results should help to choose the container, which will be the most suitable for the frozen storage of broccoli.

\section{Materials and methods}

\section{Material}

The experimental material was the broccoli (Brassica oleracea l. var. italica) cultivar $\operatorname{Lord}_{F 1}$, which was purchased in five direct sale markets located in Krakow (Poland). The broccoli examined derived from the Autumn harvest. Its pre-processing included the following operations: rejection of leaves, washing, and dividing into roses 4-6 cm in diameter and $5 \mathrm{~cm}$ in length. The process of blanching was carried out in water at $92-98{ }^{\circ} \mathrm{C}$ for 2-3 min. After blanching, the material was chilled and dried at room temperature for about $20 \mathrm{~min}$. Afterwards, the material was divided by half and packed in two types of container: half of the samples in the low density polyethylene (PE-LD) bags with the zipper closure $\left(0.915-0.935 \mathrm{~g} / \mathrm{cm}^{3}\right.$ in density and $230 \times 320 \mathrm{~mm}$ in size); and the remainder in the sealed oriented polystyrene (OPS) boxes $\left(216 \times 176 \times 75 \mathrm{~mm}\right.$ in size and $1.05 \mathrm{~g} / \mathrm{cm}^{3}$ in density). Next, the samples were sealed hermetically and kept at $-22{ }^{\circ} \mathrm{C}$ in a Liebherr GTS 3612 chamber freezer (Germany). Analyses were carried out on the raw material, the material blanched, and the frozen product. Frozen samples were analyzed after 24 hours as well as after one, two and three months of frozen storage.

\section{Analytical methods}

The experimental material taken from every container (on average: 3 roses differing in diameter - from the smallest up to the largest) was homogenized using a homogenizer (CAT type X 120) in order to obtain a mean representative sample and next was used to prepare methanol extracts ( $5 \mathrm{~g}$ of raw vegetables in $80 \mathrm{~cm}^{3}$ of $70 \%$ methanol solution). In each case, fresh plant materials were extracted by shaking (Elpan, water bath shaker type 357 ) at room temperature for 2 hours, and solution was centrifuged (Centrifuge type MPW-340), filtered and then the extracts were stored at $-22{ }^{\circ} \mathrm{C}[16]$.

The samples were analyzed in terms of vitamin $\mathrm{C}$ content (as a sum of ascorbic and dehydroascorbic acids) and $\beta$-carotene content using column chromatography. The content of vitamin $\mathrm{C}$ was determined as the sum of ascorbic acid and dehydroascorbic acid using 
2,6-dichlorophenoloindophenol according to PN-A-04019:1998 [17]. Oxalic acid solution was used for extraction of the ascorbic acid.

$\beta$-carotene analysis consisted of the extraction procedures of pigment, followed by liquid/liquid partitioning with hexane, concentration and column chromatography according to PN-90/A-75101/12 [18]. The extract was loaded onto the columns (150 $\cdot 10 \mathrm{~mm}$, packed with aluminium oxide to a length of $100 \mathrm{~mm}$ and covered with a $10 \mathrm{~mm}$ of anhydrous sodium sulphite) and then were washed with hexane containing $1 \%$ acetone. The orange-coloured eluent containing $\beta$-carotene was collected to a volumetric flask. The concentration of $\beta$-carotene was measured at $450 \mathrm{~nm}$ in a RayLeigh UV-1800 spectrophotometer and compared with a $\beta$-carotene reference standard.

Simultaneously, $70 \%$ methanol extracts has been prepared to determine: total polyphenols (calculated per chlorogenic acid) - through the colorimetric measurement of colourful substances formed due to the reaction between phenolic compounds and a Folin-Ciocalteau reagent (Sigma) [19] and to determine antioxidant activity based on the ABTS $^{\cdot+}$ free radical scavenging ability - by a colorimetric assessment of an amount of the $\mathrm{ABTS}^{\cdot+}$ free radical solution, which had not been reduced by the antioxidant present in the products examined [20].

The content of total phenols in the extracts was determined spectrometrically (at a wavelength of $760 \mathrm{~nm}$ using a RayLeigh UV-1800 spectrophotometer) according to the Folin-Ciocalteu procedure and calculated as chlorogenic acid equivalents (CGA) (in terms of milligrams) per $100 \mathrm{~g}$ of fresh or dry weight, based on a standard curve.

The method involved colorimetric determination of the amount of the colored solution of $\mathrm{ABTS}^{\cdot+}$ free radical (2, 2'-azinobis-(3-ethylbenzothiazoline-6-sulfonic acid) which was reduced by the antioxidants present in the test product. The absorbance was measured at a wavelength of $734 \mathrm{~nm}$ using a RayLeigh UV-1800 spectrophotometer. Values obtained for each sample were compared to the concentration-response curve of the standard trolox solution and expressed as micromoles of Trolox equivalent per gram of fresh or dry weight (TEAC).

\section{Statistical analysis}

All analyses were carried out in three parallel replications and mean $\pm S D$ were calculated for the values obtained. In the investigated broccoli cultivar, the significance of differences between vitamin $\mathrm{C}$ content, $\beta$-carotene content, total polyphenols as well as ability to scavenge the $\mathrm{ABTS}^{\cdot+}$ free radical and the processes applied (blanching, freezing, frozen storage) as well as a type of the container used, was established using single- and two-factor analysis of variance. By the use of one-way analysis of variance, the significance of differences were checked between mean values of: (1) raw and blanched, (2) stored in two different types of packaging, (3) different storage time. Two-way analysis of variance was used to demonstrate the significance of differences between the values of the evaluated parameters for blanched vegetables, frozen and frozen stored, depending on the type of packaging and time of frozen storage. The significance of differences was estimated with Duncan test at the critical significance level of $p<0.05$. 


\section{Results and discussion}

\section{Vitamin C}

As the dry matter content in the vegetable varies depending on the process applied and the container used, all the results presented below along with conclusions have been discussed basing on the results calculated per the dry matter unit.

It has been revealed that blanching resulted in a $30.2 \%$ fall in the level of vitamin $\mathrm{C}$ in the broccoli examined compared to the fresh vegetable, the fall being statistically significant $p<0.05$ ) (Table 1).

Table 1

Content of vitamin $\mathrm{C}, \beta$-carotene, total polyphenols and antioxidant activity in raw and blanched broccoli

\begin{tabular}{|c|c|c|c|}
\hline \multirow{2}{*}{\multicolumn{2}{|c|}{ Compounds }} & Raw & Blanched \\
\hline & & $X \pm S D^{1}$ & $X \pm S D^{1}$ \\
\hline Vitamin C & [mg/100 g d.m.] & $818^{\mathrm{a}} \pm 44$ & $571^{\mathrm{b}} \pm 43$ \\
\hline$\beta$-carotene & [ $\mu \mathrm{g} / 100 \mathrm{~g}$ d.m. $]$ & $5470^{\mathrm{a}} \pm 64$ & $5355^{\mathrm{a}} \pm 45$ \\
\hline Total polyphenols & [mg CGA/100 g d.m.] & $1302^{\mathrm{a}} \pm 75$ & $1292^{\mathrm{a}} \pm 91$ \\
\hline Antioxidant activity & [ $\mu$ mol Trolox/g d.m.] & $76.3^{\mathrm{a}} \pm 0.1$ & $74.7^{\mathrm{a}} \pm 3.1$ \\
\hline
\end{tabular}

The values denoted with the same letters do not differ statistically significantly at $p<0.05$

${ }^{1}$ Values are presented as mean value \pm standard deviation $(n=3)$

As a result of freezing, a $28.1 \%$ statistically significant $(p<0.05)$ decrease in vitamin $\mathrm{C}$ content was noted only in the case of the broccoli stored in OPS boxes, when compared to the blanched vegetable (Table 2).

Content of vitamin $\mathrm{C}$ in frozen broccoli [mg/100 $\mathrm{g} \mathrm{d.m.]}$

\begin{tabular}{|c|c|c|}
\hline \multirow{2}{*}{ Time of frozen } & \multicolumn{2}{|c|}{$\boldsymbol{X} \pm \boldsymbol{S D}^{\mathbf{1}}$} \\
\cline { 2 - 3 } & \multicolumn{2}{|c|}{ Kind of packaging } \\
\cline { 2 - 3 } & Zipper bags (PE-LD) & Boxes (OPS) \\
\hline 24-hours & $565.5^{\mathrm{a}} \pm 6.3$ & $410.8^{\mathrm{b}} \pm 4.9$ \\
\hline 1 month & $531.7^{\mathrm{a}} \pm 7.6$ & $398^{\mathrm{b}} \pm 20$ \\
\hline 2 months & $433^{\mathrm{b}} \pm 46$ & $267^{\mathrm{c}} \pm 34$ \\
\hline 3 months & $294^{\mathrm{c}} \pm 23$ & $101^{\mathrm{d}} \pm 19$ \\
\hline $\begin{array}{c}\text { Mean value } \\
\text { for packaging }\end{array}$ & $479^{\mathrm{A}} \pm 12$ & $350^{\mathrm{A}} \pm 18$ \\
\hline
\end{tabular}

The values denoted with the same small or capital letters do not differ statistically significantly at $p<0.05$

${ }^{1}$ Values are presented as mean value \pm standard deviation $(n=3)$

After 1 month of frozen storage of broccoli in OPS boxes, successive and statistically significant $(p<0.05)$ falls in vitamin C content of $30.3 \%$ were noted, compared to the blanched vegetable. After 2-month and 3-month periods of frozen storage, further losses (statistically significant, $p<0.05$ ) in this constituent were recorded for both the broccoli stored in OPS containers and those kept in PE-LD bags and compared with the blanched vegetable were respectively: 53.2 and $82.2 \%$ : for the product stored in OPS boxes; and 24.1 and $48.5 \%$ : for the broccoli kept in PE-LD bags.

It has been proved that type of the container used had no significant effect $(p>0.05)$ on the level of vitamin $\mathrm{C}$ in the vegetable investigated (Table 2). 
In Brassicas vitamin $\mathrm{C}$ is associated with the products of glucosinolate breakdown paths, for example, glucobrassicin and neo-glucobrassicin [21]. In the present work, the raw broccoli contained $95.4 \mathrm{mg}$ vitamin $\mathrm{C}$ per $100 \mathrm{~g}$ fresh vegetable, which agrees with the findings reported by Howard et al. [22] and Kurilich et al. [23]; whereas, in Singh's et al. [24] estimation, the mean value of this constituent was at the level $52.9 \mathrm{mg} / 100 \mathrm{~g}$ fresh vegetable. Sikora et al. [25] found that broccoli had $66.4 \mathrm{mg}$ vitamin $\mathrm{C} / 100 \mathrm{~g}$ fresh vegetable. Other authors reported lower amounts of vitamin $\mathrm{C}$ in fresh broccoli than these obtained in this work [26, 27]. Kurilich et al. [23] and Vallejo et al. [28], who examined 50 various broccoli cultivars originated from USA and 14 from Spain, found that vitamin C content fluctuated between 55.3 and $119.8 \mathrm{mg} / 100 \mathrm{~g}$ fresh vegetable in American cultivars and 43.2 and $146.3 \mathrm{mg} / 100 \mathrm{~g}$ fresh vegetable in Spanish cultivars. According to the literature, vitamin $\mathrm{C}$ content in the vegetable investigated may be affected by numerous factors such as vegetable cultivar, agro-technical and climatic conditions, length of maturity, exposure to the sun, enzymatic activity, fertilization, and environment pollution $[25,29]$.

Technological treatments, i.a., blanching, proceeded by preliminary processing (washing, peeling, comminuting) may lead to considerable losses in antioxidants, mainly in vitamin $\mathrm{C}$ content. The extent of such losses depends on the temperature applied and length of its application as well as the degree of product comminuting [25]. In the present work, vitamin $\mathrm{C}$ content decreased by about $30 \%$ due to blanching, which is not in agreement with the findings of Cai et al. [27], who noted that the content of vitamin $\mathrm{C}$ in blanched broccoli florets remained and the same level as in the fresh vegetable. Conditions under which blanching is conducted along with the vegetable cultivar have a substantial effect on the later composition of the product. Amin et al. [30] estimated the percentage losses in this constituent after such thermal processing at 18-49\% that also corresponds with our results. The similar value was also reported by Severini et al. [31], while Volden et al. [32], reported losses within the range 19-26\% in the same vegetable from Brassicas, compared to the fresh vegetable.

Gonzalez-Hidalgo et al. [33] found that immediately after freezing broccoli, changes in the level of the constituent examined were statistically significant that has been confirmed by the results obtained in this work but only with respect to the experimental material stored in OPS boxes. In the case of broccoli kept in PE-LD bags for 24 hours retention was instatistically significant. Compared to the product stored in OPS boxes, the vegetable stored in PE-LD bags exhibited lower losses in this constituent that could result from better impermeability of such bags, which better limit the access of oxygen and hence the process of constituents' oxidation occurring in the stored experimental material. However, Li et al. [26] noted no statistically significant differences for vitamin $C$ compared to the fresh material. In the broccoli investigated in this paper, a continuous decline in the level of vitamin $\mathrm{C}$ (on average of $65.5 \%$ ) was observed throughout a period of frozen storage period, when compared to the blanched material. A considerable reduction in nutrients and vitamin $\mathrm{C}$ during storage of the frozen product could have resulted from insufficient inactivation of oxidoreductive enzymes during the process of blanching. Efficacious inactivation of peroxydases during blanching can lead to higher vitamin content in the vegetable having undergone frozen storage. Properly-conducted blanching is a fundamental technological operation prior to the period of frozen storage; however, attention should be paid to the process parameters as well as the length of this operation [34]. In addition, ice crystals formed during freezing can contribute to the vitamin $\mathrm{C}$ reduction damaging the 
vegetable tissue. The other factor may be temperature fluctuation, which make greater losses in this vitamin by enhancing the loss-in-weight phenomenon [35].

\section{$\beta$-carotene}

There were no significant changes $(p>0.05)$ due to blanching in the levels of $\beta$-carotene, compared to the raw broccoli (Table 1).

With regard to the vegetable stored in OPS boxes, the process of freezing resulted in a $10.3 \%$ reduction in the constituent examined compared to the blanched vegetable and this reduction was statistically significant $(p<0.05)$ (Table 3$)$. The successive statistically significant $(p \leq 0.05)$ losses in this constituent in broccoli stored in OPS container and PE-LD bags, compared with the blanched vegetable, were respectively: 14.9 and $12.1 \%$ : after 1-month storage; 22.7 and $20.4 \%$ : after 2-month storage; and 24.5 and $22.3 \%$ : after 3-month storage.

A type of the container used was not found to have a significant effect $(p>0.05)$ on the level of $\beta$-carotene in the vegetable investigated (Table 3).

Table 3

Content of $\beta$-carotene in frozen broccoli [ $\mu \mathrm{g} / 100 \mathrm{~g}$ d.m.]

\begin{tabular}{|c|c|c|}
\hline \multirow{2}{*}{ Time of frozen } & \multicolumn{2}{|c|}{$\boldsymbol{X} \pm$ S $\boldsymbol{D}^{\mathbf{1}}$} \\
\cline { 2 - 3 } & \multicolumn{2}{|c|}{ Kind of packaging } \\
\cline { 2 - 3 } & Zipper bags (PE-LD) & Boxes (OPS) \\
\hline 24-hours & $5275.2^{\mathrm{a}} \pm 7.7$ & $5071.3^{\mathrm{b}} \pm 7.1$ \\
\hline 1 month & $4708.8^{\mathrm{c}} \pm 6.9$ & $4555^{\mathrm{c}} \pm 18$ \\
\hline 2 months & $4259.8^{\mathrm{d}} \pm 9.8$ & $4137.5^{\mathrm{d}, \mathrm{e}} \pm 9.1$ \\
\hline 3 months & $4160.4^{\mathrm{d}, \mathrm{e}} \pm 2.1$ & $4041.1^{\mathrm{e}} \pm 4.8$ \\
\hline $\begin{array}{c}\text { Mean value } \\
\text { for packaging }\end{array}$ & $4376^{\mathrm{A}} \pm 29$ & $4651^{\mathrm{A}} \pm 66$ \\
\hline
\end{tabular}

The values denoted with the same small or capital letters do not differ statistically significantly at $p<0.05$

${ }^{1}$ Values are presented as mean value \pm standard deviation $(n=3)$

The results obtained in this work on $\beta$-carotene content are within the broad range established by Singh et al. [24]. The content of $\beta$-carotene determined by the authors mentioned ranged in 480-1130 $\mu \mathrm{g} / 100 \mathrm{~g}$ f.m. of the product; whereas, according to Holden et al. [36] it was $780 \mu \mathrm{g} / 100 \mathrm{~g}$ edible part. This constituent was to a large extent affected by the vegetable cultivar, climate and weather conditions, and a method of cultivation, among other factors.

The work presented here proved that there were no significant losses in the level of this constituent due to blanching but only a decrease of $2.1 \%$, which agrees with the finding reported by Cai et al. [27]. This phenomenon was explained by Khachik et al. [37] by the location of $\beta$-carotene in the cell's chloroplasts that assures thermal protection and prevents against its greater losses.

Cai et al. [27] reported an increase (about $21 \%$ ) of $\beta$-carotene in broccoli during frozen storage compared to the raw and blanched material. In the study of Alanís-Garza et al. [38] broccoli subjected to industrial freezing showed higher levels of total carotenoids ( 60-300 \% higher) as compared with fresh broccoli. The authors suggest that bioactive compounds in frozen broccoli would be more bioavailable than in raw. In this work the final mean losses after 3 months of frozen storage were $21 \%$. According to Howard et al. [22], vegetables having undergone fast freezing immediately after harvest retained above 
$70 \%$ of this constituent after one-year frozen storage. Studies of Kmiecik and Lisiewska [39] revealed that freezing of unblanched spring onion resulted in a $17 \%$ decrease in $\beta$-carote $\sqsubset$; whereas, the losses due to freezi $\llbracket g$ the bla $\sqsubset$ ched material were $10-13 \%$ compared to the fresh vegetable. According to these authors, 12-month frozen storage of the unblanched spring onion led to particularly high losses in $\beta$-carotene of $56 \%$ at $-20{ }^{\circ} \mathrm{C}$ and $32 \%$ at $-30{ }^{\circ} \mathrm{C}$, when compared to its level immediately after freezing. Frozen storage of tomatoes at -20 and $-30{ }^{\circ} \mathrm{C}$ caused decreases in this constituent of respectively: 21 and $7 \%$ : after 6 - mo th storage; a $\square 36$ a $\square 17 \%$ : after 12-month storage, as was reported by Lisiewska and Kmiecik [40]. Losses in $\beta$-carotene during freezing parsley leaves reported by these authors in their previous studies were $27 \%$ in the unblanched material, while in the blanched material this constituent was in trace amounts. According to these authors, during frozen storage at different temperatures, i.e., -20 and $-30{ }^{\circ} \mathrm{C}$, the greatest losses of $\beta$-carotene were found in the unblanched material stored at $-20^{\circ} \mathrm{C}$ [41]. Throughout frozen storage of the blanched dill, the level of this provitamin remained unchanged until $12^{\text {th }}$ month [42]. Insignificant losses of $\beta$-carotene in spinach after 12-month frozen storage were also observed by Jaworska and Kmiecik [43]. According to the findings of Jaworska and Kmiecik [43], the losses of this constituent were the lowest in blanched vegetables which were frozen-stored at $-30{ }^{\circ} \mathrm{C}$, since blanched and frozen-stored vegetables, among others, spinach, spring onion and selected parts of beetroot contained of 12-13\% more $\beta$-carotene than the material unblanched.

\section{Total polyphenols}

There were no significant changes $(p>0.05)$ due to blanching in the levels of total polyphenols, compared to the raw broccoli (Table 1).

Both freezing and 1 month's frozen storage of the examined material, led to significant $(p<0.05)$ decreases in these substances in the broccoli kept in OPS boxes and in PE-LD bags of $\sim 27.5$ and $\sim 19.5 \%$, respectively (Table 4 ).

After 2 and 3 month's frozen storage, there were no statistically significant $(p>0.05)$ changes in total polyphenols compared to the blanched vegetables. The effect of the container type on the level of total polyphenols in the vegetable examined was not statistically significant $(p>0.05)$ (Table 4).

Table 4

Content of total polyphenols in frozen broccoli [mg CGA/100 g d.m.]

\begin{tabular}{|c|c|c|}
\hline \multirow{2}{*}{ Time of frozen } & \multicolumn{2}{|c|}{$\boldsymbol{X} \pm$ S $\boldsymbol{D}^{\mathbf{1}}$} \\
\cline { 2 - 3 } & \multicolumn{2}{|c|}{ Kind of packaging } \\
\cline { 2 - 3 } & Zipper bags (PE-LD) & Boxes (OPS) \\
\hline 24-hours & $1025^{\mathrm{b}} \pm 34$ & $930^{\mathrm{b}} \pm 44$ \\
\hline 1 month & $1023^{\mathrm{b}} \pm 48$ & $944^{\mathrm{b}} \pm 63$ \\
\hline 2 months & $1344^{\mathrm{a}} \pm 71$ & $1385.7^{\mathrm{a}} \pm 9.9$ \\
\hline 3 months & $1286^{\mathrm{a}} \pm 52$ & $1345^{\mathrm{a}} \pm 50$ \\
\hline $\begin{array}{c}\text { Mean value } \\
\text { for packaging }\end{array}$ & $1194^{\mathrm{A}} \pm 16$ & $1179^{\mathrm{A}} \pm 22$ \\
\hline
\end{tabular}

The values denoted with the same small or capital letters do not differ statistically significantly at $p<0.05$

${ }^{1}$ Values are presented as mean value \pm standard deviation $(n=3)$

The results obtained in this work for total polyphenols correspond to those reported by some authors, for example, Patras et al. [44], Turkmen et al. [45], or Singh et al. [24]; 
although, according to the findings of Sikora et al. [25] the level of total polyphenols was $289 \mathrm{mg} / 100 \mathrm{~g} \mathrm{f.m}$. of the vegetable that was almost twice the content of these constituents determined in the present study (151.9 mg CGA per $100 \mathrm{~g}$ fresh vegetable). Any comparison between the results obtained in other experiments would be problematic in view of the wide range of possibilities for choosing parameters of extraction and various methods of polyphenols' determination. Moreover, the extractants used have various composition and $\mathrm{pH}$; the process of extraction may be conducted at various temperatures and for a different time; and the proportion of plant material to the solvent may also vary. Furthermore, the differences between the results obtained by various researchers may also result from the experimental material alone. Chemical composition of the fresh vegetables depends on many factors, among other, agrotechnical conditions and cultivar. A large discrepancy in the level of this constituent due to the aforementioned factors causes that they may vary from the mean value in the range of -50 to $+175 \%[7,8]$.

In this work, blanching reduced the level of total polyphenols. A decrease reported by Sikora et al. [25] was approx. $14 \%$, that is $5 \%$ more than in the material analyzed in this paper. Lima et al. [46] claims that migration of polyphenols to water is one of reasons for a decline in their concentration. According to Cai et al. [27], the process of blanching leads to inreases in total polyphenol content in the broccoli of $25.9 \%$. Heating the raw material in water causes that heat permeates relatively quickly into the tissue interior. As a result, the whole volume of the product undergoing processing is longer exposed to the temperature that in turn leads to high losses in antioxidants. Blanching results in losses of constituents but on the other hand the process affects inactivation of the enzymes responsible for the decomposition of natural antioxidants, which was highlighted by Barrett et al. [47]. Therefore, this process is essential since vegetables and fruits which were earlier subjected to blanching retain to a greater extent their antioxidant activity throughout storage.

According to some authors $[25,48]$, the freezing itself is responsible for higher losses in total polyphenols (30-40\%) than those found in the present work. In the study of Gonzalez-Hidalgo et al. [34] the losses of phenolic compound after industrial freezing reached about $57 \%$ in comparison to blanched vegetable. In the case of the broccoli

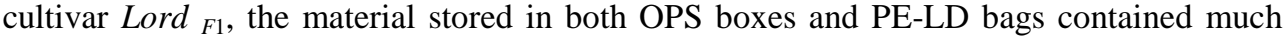
more total polyphenols. However, in this experiment, the length of freezing was shorter twice (24 hours); temperature was lower $\left(-22^{\circ} \mathrm{C}\right)$; and the results were calculated per chlorogenic acid, which can have an effect on the discrepancy in the results.

In this study the decrease in total polyphenols was continuing by the second month of research; next the level of these constituents increased substantially to be continued at high level, near the level in the blanched material, until the end of a study period. An increase in the level of these constituents to the value even exceeding the initial value has also been confirmed by Kaluzewicz et al. [49] and Kim et al. [50]; however, an increase noted in this research did not exceeded the level determined in the fresh vegetable. As Hakkinen and Torronen [51] claim, throughout several months of storage of strawberries, both an increase and a decrease in total polyphenols were possible. They stated that an increase in total polyphenols in the products examined could be attributed to the physiological response of the plant organism to infections or injuries resulting in the release of such substances. Furthermore, the method used to determine the content of total polyphenols may also have an effect on the results obtained, since the Folina-Ciocalteu reagent can also react with other constituents such as sugars, ascorbic acid, proteins, amino acids, as well as cuprum and iron ions [52]. 


\section{Antioxidant activity}

As in the case of $\beta$-carotene and total polyphenols, the changes observed in antioxidant activity due to this process were also insignificant $(p>0.05)$ in comparison with the raw material (Table 1). A statistically significant $(p<0.05)$ reduction in antioxidant activity compared to the blanched material was observed due to freezing and 1 month's storage and the losses were respectively: $\sim 16.9 \%$ in the vegetables stored in OPS boxes; and $\sim 5.6 \%$ in those kept in PE-LD bags (Table 5).

Antioxidant activity of frozen broccoli [ $\mu \mathrm{mol}$ Trolox/g d.m.]

Table 5

\begin{tabular}{|c|c|c|}
\hline \multirow{2}{*}{ Time of frozen } & \multicolumn{2}{|c|}{$\boldsymbol{X} \pm \boldsymbol{S} \boldsymbol{D}^{\mathbf{1}}$} \\
\cline { 2 - 3 } & \multicolumn{2}{|c|}{ Kind of packaging } \\
\cline { 2 - 3 } & Zipper bags (PE-LD) & Boxes (OPS) \\
\hline 24-hours & $68.90^{\mathrm{c}} \pm 0.01$ & $61.6^{\mathrm{d}} \pm 1.7$ \\
\hline 1 month & $72.1^{\mathrm{b}, \mathrm{c}} \pm 2.2$ & $62.5^{\mathrm{d}} \pm 1.0$ \\
\hline 2 months & $73.8^{\mathrm{a}, \mathrm{b}, \mathrm{c}} \pm 3.2$ & $77.8^{\mathrm{a}} \pm 2.3$ \\
\hline 3 months & $73.4^{\mathrm{a}, \mathrm{b}, \mathrm{c}} \pm 0.2$ & $77.3^{\mathrm{a}, \mathrm{b}} \pm 2.2$ \\
\hline $\begin{array}{c}\text { Mean value } \\
\text { for packaging }\end{array}$ & $72.6^{\mathrm{A}} \pm 2.2$ & $70.8^{\mathrm{A}} \pm 8.1$ \\
\hline
\end{tabular}

The values denoted with the same small or capital letters do not differ statistically significantly at $p<0.05$

${ }^{1}$ Values are presented as mean value \pm standard deviation $(n=3)$

After 2 and 3 month of frozen storage, changes in antioxidant activity were not statistically significant $(p>0.05)$ compared to the blanched vegetables. At the same time, there were no statistically significant $(p>0.05)$ changes in antioxidant activity between vegetables stored in two different containers (Table 5).

Antioxidant activity in the broccoli cultivar Sebastian reported by Sikora et al. [25] ( $26.2 \mu$ mol Trolox $/ 1 \mathrm{~g}$ fresh vegetable) was almost three times higher than that determined in this work $(8.9 \mu \mathrm{mol}$ Trolox/1 $\mathrm{g}$ fresh vegetable). The results obtained by Bahorun et al. [53] and Cao et al. [54] were slightly lower than those received in this study; however, the latter applied a different analytical method. On the other hand, the level of antioxidant activity detected by Murcia et al. [55] (1.8 $\mu \mathrm{mol}$ Trolox/1 g f.m.) corresponded to the results found in this work. The differences observed between values of antioxidant activity once again confirm the fact that chemical composition of broccoli as well as cultivation conditions plays an important role in modelling its chemical composition. It is worthwhile to mention here that the values calculated may differ depending on the analytical method used (ABTS, DPPH, FRAP, ORAC, and so on), the measuring devices applied, as well as a manner of expressing antioxidant potential (as the percentage of free radical scavenging or as the Trolox equivalent) [26].

Changes in antioxidant activity in vegetables throughout their storage are associated with those occurring in the levels of constituents showing antioxidant properties (particularly in vitamin $\mathrm{C}$ and total polyphenols) as well as with the fact that they interact mutually [56]. The production of reactive oxygen species (ROS) is normally carefully controlled by the plants, which possess specific antioxidant enzymes such as peroxidase, catalase and superoxide dismutase and low-molecular weight antioxidants like ascorbate, glutathione, tocopherols, flavonoids and carotenoids. Imbalance between the formation of ROS and action of a protective antioxidant system leads to oxidative stress, especially when plants are exposed to abiotic stress [57]. 
In comparison with the raw vegetable, the process of blanching caused only a slight decrease (of $2.1 \%$ ) in antioxidant activity in the broccoli investigated, which agrees with the findings of Sikora et al. [25] and Gonzalez-Hidalgo et al. [33]. Antioxidant activity determined by Cai et al. [30] in the extract of blanched cauliflower was higher of $\sim 23.4 \%$. On the other hand Volden et al. [34] observed that a fall in this parameter ranged in 10-31\%. A decline in antioxidant activity was also observed by Radosevic et al. [58]. Amin et al. [31] maintain that blanching may cause even $50 \%$ decrease in antioxidant activity.

According to Sikora et al. [25], antioxidant activity determined in vegetables immediately after freezing is similar to that after blanching. Murcia et al. [55], after 24 hour storage, reported anthocyanin activity losses of $1.6 \%$, which compared to our results $(\sim 12.6 \%)$ were lower. It should be emphasised however that the vegetable examined by those authors was not blanched that probably reduced losses in antioxidants and allowed this parameter to be maintained at high level. Gonzalez-Hidalgo et al. [33] reported that after frozen storage the antioxidant activity of broccoli was similar in comparison to blanched and fresh vegetable, although this was not confirmed by the results obtained in this work. In this research, an increase in this parameter in frozen broccoli was noted: after two months: for the broccoli stored in OPS boxes; and after one month: for the product kept in PE-LD bags. Leja et al. [59], who examined white cabbage, also reported that after several months of frozen storage, its capability to scavenge free radicals increased. This was additionally confirmed by the findings of Starzynska et al. [60], who registered such an increase in broccoli, however stored at room temperature. Both high and low temperature may be a factor inducing oxidative changes in the plant material. Moreover, the aforementioned authors observed a rise in enzymatic activity in frozen-stored broccoli with respect to such enzymes like superoxide dismutase, catalase or peroxidase. Good free radical scavenging ability demonstrated by broccoli may probably be attributed to the fact that one of their main polyphenol compound is quercetin recognized as a very good scavenger of the $\mathrm{ABTS}^{\circ+}$ cation radicals [61]. As Frati et al. [62] showed, freezing of broccoli resulted in loss of $50.0 \%$ of antioxidant activity. Despite this, the authors reported that frozen vegetables are stable 24 months under optimal sanitary conditions and represent a good alternative to fresh products.

\section{Conclusions}

Numerous epidemiological and pharmacological studies have revealed that the diet rich in Brassica vegetables may play an important role in the protection of many chronic diseases. In most cases Brassicas are not eaten immediately after being harvested, hence storage and cooking impact upon health beneficial components. Processing of Brassica vegetables has complex influences on the food matrix affecting the level of many ingredients. Freezing is one of the simplest, fastest as well as the most universal and convenient ways of preserving food.

After 3 months of frozen storage of vegetables packed in PE-LD bags and OPS containers, mean losses in the constituents examined were: $\sim 65.3 \%$ in vitamin $\mathrm{C}$ (decrease); $23.4 \%$ in $\beta$-carotene (decrease); $3.4 \%$ in total polyphenols (increase); and $2.6 \%$ in antioxidant potential (increase).

In this study was observed no change in total polyphenols content and antioxidant activity after frozen stored of broccoli in comparison to blanched vegetables. These results confirm the positive effect of the freezing process on maintaining the health quality of 
vegetables. A type of the container used did not affect significance of differences in terms of vitamin $\mathrm{C}$ content, $\beta$-carotene content, total polyphenol content, and antioxidant potential of frozen-stored broccoli stored in such containers. It is therefore an incentive to further search for packaging materials for storing frozen vegetables.

\section{References}

[1] Sharma A, Li X, Lim YP. Comparative genomics of Brassicaceae crops. Breed Sci. 2014;64:3-13. DOI: 10.1270/jsbbs.64.3.

[2] Kapusta-Duch J, Kusznierewicz B, Leszczyńska T, Borczak B. Effect of cooking on the contents of glucosinolates and their degradation products in selected Brassica vegetables. $\mathrm{J}$ Funct Foods. 2016;23:412-422. DOI: 10.1016/j.jff.2016.03.006.

[3] Sturm C, Wagner AE. Brassica-derived plant bioactives as modulators of chemopreventive and inflammatory signaling pathways. Int J Mol Sci. 2017;18:1-26. DOI:10.3390/ijms18091890.

[4] Aslani BA, Ghobadi S. Studies on oxidants and antioxidants with a brief glance at their relevance to the immune system. Life Sci. 2016;146:163-173. DOI: 10.1016/j.lfs.2016.01.014.

[5] Mérillon JM, Ramawat KG, editors. Glucosinolates. Basel: Springer International Publishing; 2017. ISBN: 9783319254623. DOI: 10.1007/978-3-319-25462-3.

[6] Abellán Á, Domínguez-Perles R, Moreno DA, García-Viguera C. Sorting out the value of cruciferous sprouts as sources of bioactive compounds for nutrition and health. Nutrients. 2019;11:429. DOI: 10.3390/nu11020429.

[7] Kapusta-Duch J, Kusznierewicz B, Leszczyńska T, Borczak B. Effect of conventional cooking on changes in the contents of basic composition and glucosinolates in kale. Ecol Chem Eng A. 2016;23(4):465-480. DOI: 10.2428/ecea.2016.23(4)31.

[8] Barba FJ, Esteve MJ, Frígola A. Bioactive components from leaf vegetable products. Studies Natural Products Chem. 2014;41:321-346. DOI: 10.1016/B978-0-444-63294-4.00011-5.

[9] Poprac P, Jomova K, Simunkova M, Kollar V, Rhodes CJ, Valko M. Targeting free radicals in oxidative stress-related human diseases. Trends Pharmacol Sci. 2017;38:592-607. DOI: 10.1016/j.tips.2017.04.005.

[10] Figueroa-Méndez R, Rivas-Arancibia S. Vitamin C in health and disease: its role in the metabolism of cells and redox state in the brain. Front Physiol. 2015;6:397. DOI: 10.3389/fphys.2015.00397.

[11] Padayatty SJ, Levine M. Vitamin C: the known and the unknown and goldilocks. Oral Dis. 2016;22:463-493. DOI: 10.1111/odi.12446.

[12] Young A, Lowe G. Carotenoids - antioxidant properties. Antioxidants. 2018;7:28. DOI: 10.3390/antiox7020028.

[13] Fuentes F, Paredes-Gonzalez X, Kong ANT. Dietary glucosinolates sulforaphane, phenethyl isothiocyanate, indole-3-carbinol/3,3'-diindolylmethane: anti-oxidative stress/inflammation, nrf2, epigenetics/epigenomics and in vivo cancer chemopreventive efficacy. Curr Pharmacol Rep. 2015;1:179-196. DOI: 10.1007/s40495-015-0017-y.

[14] Avato P, Argentieri MP. Brassicaceae: a rich source of health improving phytochemicals. Phytochem Rev. 2015;14:1019-1033. DOI: 10.1007/s11101-015-9414-4.

[15] Barba FJ, Nikmaram N, Roohinejad S, Khelfa A, Zhu Z, Koubaa M. Bioavailability of glucosinolates and their breakdown products: Impact of processing. Front Nutr. 2016;16:24. DOI: 10.3389/fnut.2016.00024.

[16] Pellegrini N, Del Rio D, Colombi B, Bianchi M, Brighenti F. Application of the 2'2-azobis (3-ethylenebenzothiazoline-6-sulfonic acid) radical cation assay to flow injection system for the avaluation of antioxidant activity of some pure compounds and bevereges. J Agric Food Chem. 2003;51:164-260. DOI:10.1021/jf020657z.

[17] PN-A-04019:1998. Polski Komitet Normalizacyjny. Produkty spożywcze. Ogólne metody badań i analiz produktów spożywczych - Oznaczanie zawartości witaminy C. (Polish Standard. 1998. PN-A-04019:1998. Polish Committee for Standardization. Food products - Determination of vitamin C). http://sklep.pkn.pl/pn-a-04019-1998p.html.

[18] Polski Komitet Normalizacyjny. Przetwory owocowe i warzywne -- Przygotowanie próbek i metody badań fizykochemicznych -- Oznaczanie zawartości sumy karotenoidów i beta-karotenu. (Polish Standard. 1990. PN-90/A-75101/12. Polish Committee for Standardization. Food products - Determination of total carotenoids and $\beta$-carotene). http://sklep.pkn.pl/pn-a-75101-12-1990p.html.

[19] Hillis WE, Swain T. The phenolic constituents of Prunus domestica. II. - The analysis of tissues of the Victoria plum tree. J Sci Food Agric. 1959;10:135-144. DOI: 10.1002/jsfa.2740100211. 
[20] Re R, Pellegrini N, Proteggente A, Pannala A, Yang M, Rice-Evans C. Antioxidant activity applying an improved ABTS radical cation decolorization assay. Free Radic Biol Med. 1999;26:1231-1237. DOI: 10.1016/S0891-5849(98)00315-3.

[21] Hrncirik K, Valusek J, Velisek J. Investigation of ascorbigen as a breakdown product of glucobrassicin autolysis in Brassica vegetables. Eur Food Res Technol. 2001;212:576-581. DOI: 10.1007/s002170100291.

[22] Howard LA, Wong AD, Perry AK, Klein BP. $\beta$-carotene and ascorbic acid retention in fresh and processed vegetables. J Food Sci. 1999;64(5):929-936. DOI: 10.1111/j.1365-2621.1999.tb15943.x.

[23] Kurilich A, Tsaui GJ, Brown A, Howard L, Klein BP, Jeffrey EH, et al. Carotene, tocopherol, and ascorbate contents in subspecies of Brassica oleracea. J Agric Food Chem. 1999;47:1576-1681. DOI: 10.1021/jf9810158.

[24] Singh J, Upadhyay AK, Prasad K, Bahadur A, Rai M. Variability of carotenes, vitamin C, E and phenolics in Brassica vegetables. J Food Comp Anal. 2007;20:106-112. http://www.academia.edu/15649258/ Variability_of_carotenes_vitamin_C_E_and_phenolics_in_Brassica_vegetables.

[25] Sikora E, Cieślik E, Leszczyńska T, Filipiak-Florkiewicz A, Pisulewski PM. The antioxidant activity of selected cruciferous vegetables subjected to aquathermal processing. Food Chem. 2008;107:55-59. DOI: 10.1016/j.foodchem.2007.07.023.

[26] Li L, Pegg RB, Eitenmiller RR, Chun JY, Kerrihard AL. Selected nutrient analyses of fresh, fresh-stored, and frozen fruits and vegetables. J Food Compos Anal. 2017;59:8-17. DOI: 10.1016/j.jfca.2017.02.002.

[27] Cai C, Miao H, Qian H, Yao L, Wang B, Wang Q. Effects of industrial pre-freezing processing and freezing handling on glucosinolates and antioxidant attributes in broccoli florets. Food Chem. 2016;210:451-456. DOI: 10.1016/j.foodchem.2016.04.140.

[28] Vallejo F, Tomas-Barberan FA, Garcia-Viguera C. Potential bioactive compounds in health promotion from broccoli cultivars grown in Spain. J Sci Food Agr. 2002;82:1293-1297.

[29] Abushita AA, Daood HG, Biacs PA. Changes in carotenoids and antioxidant vitamins in tomato as a function of varietal and technologicals factors. J Agric Food Chem. 2000;48:2075-2081. DOI: 10.1021/jf990715p.

[30] Amin I, Norazaidah Y, Hainida KI. Antioxidant activity and phenolic content of raw and blanched Amaranthus species. Food Chem. 2006;94(1):47-52. DOI: 10.1016/j.foodchem.2004.10.048.

[31] Severini C, Giuliani R, De Filippis A, Derossi A, De Pilli T. Influence of different blanching methods on colour, ascorbic acid and phenolics content of broccoli. J Food Sci Technol. 2016;53:501-510. DOI: 10.1007/s13197-015-1878-0.

[32] Volden J, Bengtsson BG, Wicklund T. Glucosinolates, L-ascorbic acid, total phenols, anthocyanins, antioxidant capacities and colour in cauliflower (Brassica oleracea L. ssp. Botrytis); effect of long-term freezer storage. Food Chem. 2009;112:967-976. DOI: 10.1016/j.foodchem.2008.07.018.

[33] González-Hidalgo I, Moreno DA, García-Viguera C, Ros-García JM. Effect of industrial freezing on the physical and nutritional quality traits in broccoli. Food Sci Technol Int. 2019;25:56-65. DOI: 10.1177/1082013218795807.

[34] Barrett DM, Garcia EL, Russell GF, Ramirez E, Shirazi A. Blanch time and cultivar effects on quality of frozen and stored corn and broccoli. J Food Sci. 2000;65(3):534-540. http://ucce.ucdavis.edu/files/datastore/234-376.pdf.

[35] Xin Y, Zhang M, Xu B, Adhikari B, Sun J. Research trends in selected blanching pretreatments and quick freezing technologies as applied in fruits and vegetables: A review. Int J Refrig. 2015;57:11-25. DOI: 10.1016/j.ijrefrig.2015.04.015

[36] Holden JM, Eldridge AL, Beecher GR, Buzzard IM, Bhagwat S, Davis CS. Carotenoids content of U.S. food: An uptade of the database. J Food Comp Anal. 1999;12:169-196. DOI: 10.1006/jfca.1999.0827.

[37] Khachik F, Goli MB, Beecher GR, Holden J, Lusby WR, Tenori MD, et al. Effect of food preparation on qualitative and qualitative distribution of major carotenoid constituents of tomatoes and several green vegetables. J Agric Food Chem.1992;40: 390-398. DOI: 10.1021/jf00015a006.

[38] Alanís-Garza PA, Becerra-Moreno A, Mora-Nieves JL, Mora-Mora JP, Jacobo-Velázquez DA. Effect of industrial freezing on the stability of chemopreventive compounds in broccoli. Int J Food Sci Nutr. 2015;66:282-288. DOI: 10.3109/09637486.2015.1007451.

[39] Kmiecik W, Lisiewska Z. Effect of pretreatment and conditions and period of stoarge on some quality indices of frozen chive (Allium schoenoprasum L.). Food Chem. 1999;67:61-66. DOI: 10.1016/S0308-8146(99)00111-9.

[40] Lisiewska Z, Kmiecik W. Effect of storage period and temperature on the chemical composition and organoleptic quality of frozen tomato cubes. Food Chem. 2000;70:167-173. DOI: 10.1016/S0956-7135(99)00110-3.

[41] Lisiewska Z, Kmiecik W. Effect of freezing and storage on quality factors in hamburg and leafy parsley. Food Chem. 1997;60(4):633-637. DOI: 10.1016/S0308-8146(97)00048-4. 
[42] Lisiewska Z, Kmiecik W, Słupski J. Contents of chlorophylls and carotenoids in frozen dill: effect of usable part and pre-treatment on the content of chlorophylls and carotenoids in frozen dill (Anethumgraveolens L.), depending on the time and temperature of storage. Food Chem. 2004;84:511-518. DOI: 10.1016/S0308-8146(03)00265-6.

[43] Jaworska G, Kmiecik W. Comparison of the nutritive value of frozen spinach and New Zealand spinach. Pol J Food Nutr Sci. 2000;9(4):79-84. http://www.ejpau.media.pl/volume4/issue2/food/art-04.html.

[44] Patras A, Stoleru V, Filimon RV, Padureanu S, Chelariu EL, Biliaderis CG. Influence of sodium and maturity stage on the antioxidant properties of cauliflower and broccoli sprouts. Not Bot Horti Agrobot Cluj Napoca. 2017;45:458-465.

[45] Turkmen N, Sari F, Velioglu YS. The effect of cooking methods on total phenolics and antioxidants activity of selected green vegetables. Food Chem. 2005;93:713-718. DOI: 10.1016/j.foodchem.2004.12.038.

[46] Lima GPP, Lopes TDVC, Rossetto MRM, Vianello F. Nutritional composition, phenolic compounds, nitrate content in eatable vegetables obtained by conventional and certified organic grown culture subject to thermal treatment. Int J Food Sci Technol. 2009;44:1118-1124. DOI: 10.1111/j.1365-2621.2009.01928.

[47] Barrett DM, Garcia EL, Russell GF, Ramirez E, Shirazi A. Blanch time and cultivar effects on quality of frozen and stored corn and broccoli. J Food Sci. 2000;65:534-540. DOI: 10.1111/j.1365-2621.2000.tb16043.x.

[48] Puupponen-Pimiä R, Häkkinen ST, Aarni M, Suortti T, Lampi AM, Eurola M, et al. Blanching and long-term freezing affect various bioactive compounds of vegetables in different ways. J Sci Food Agric. 2003;83:1389-1402. DOI: 10.1002/jsfa.1589.

[49] Kałużewicz A, Lisiecka J, Gąsecka M., Waśkiewicz A, Krzesiński W, Spiżewski T, et al. Changes in composition of phenolic compounds and tocopherols in broccoli heads during short-term storage. Żywność Nauka Technologia Jakość. 2016;3:127-139. DOI: 10.15193/zntj/2016/106/131.

[50] Kim JS, Kanga OJ, Gweon OC. Comparison of phenolic acids and flavonoids in black garlic at different thermal processing steps. J Funct Foods. 2013;5:80-86. DOI: 10.1016/j.jff.2012.08.006.

[51] Häkkinen SH, Törrönen AR. Content of flavonols and selected phenolic in strawberries and Vaccinium species: influence of cultivar, cultivation site and technique. Food Res. Int. 2000;33:517-524. DOI: 10.1016/S0963-9969(00)00086-7.

[52] Agbor GA, Vinson JA, Donnelly PE. Folin-Ciocalteau reagent for polyphenolic assay. Int J Food Sci Nutr Diet. 2014;3(8):147-156. DOI: 10.19070/2326-3350-1400028.

[53] Bahorun T, Luximon-Ramma A, Crozier A, Aruoma O. Total phenol, flavonoid, proanthocyanidin and vitamin $\mathrm{C}$ levels and antioxidant activities of Mauritian vegetables. $\mathrm{J}$ Sci Food Agric. 2004;84(12):1553-1561. DOI: 10.1002/jsfa.1820.

[54] Cao G, Sofic E, Prior RL. Antioxidant capacity of tea and common vegetables. J Agric Food Chem. 1996;44:3426-3431. DOI: 10.1021/jf9602535.

[55] Murcia MA, Lopez-Ayerra B, Garcia-Carmona F. Effect of processing and different blanching times on broccoli: proximate composition and fatty acids. Lebensm Wiss Technol. 1999;32:238-243. DOI: 10.1006/fstl.1998.0535.

[56] Shahidi F, Ambigaipalan P. Phenolics and polyphenolics in foods, beverages and spices: Antioxidant activity and health effects - A review. J Funct Foods. 2015;18:820-897. DOI: 10.1016/j.jff.2015.06.018.

[57] Rombel-Bryzek A, Rajfur M, Zhuk O. The impact of copper ions on oxidative stress in garden cress Lepidium sativum. Ecol Chem Eng S. 2017;24:627-636. DOI: 10.1515/eces-2017-0041.

[58] Radošević K, Srček VG, Bubalo MC, Brnčić SR, Takács K, Redovniković IR. Assessment of glucosinolates, antioxidative and antiproliferative activity of broccoli and collard extracts. J Food Compos Anal 2017;61:59-66. DOI: 10.1016/j.jfca.2017.02.001

[59] Leja M, Mareczek A, Adamus A, Strzetelski P, Combi M. Some antioxidative properties of selected white cabbage HD lines. Folia Hortic. 2006;18(1):31-40. http://www.ptno.ogr.ar.krakow.pl/ Wydawn/FoliaHorticulturae/Spisy/FH2006/PDF18012006/fh1801p03.pdf.

[60] Starzyńska A, Leja M, Mareczek A. Physiological changes in the antioxidant system of broccoli flower buds senescing during short-term storage, related to temperature and packing. Plant Sci. 2003;165:1385-1395. DOI: 10.1016/j.plantsci.2003.07.004.

[61] Pannala AS, Chan TS, O'brien P, Rice-Evans CA. Flavonoid B - ring chemistry and antioxidant activity: Fast reaction kinetics. Biochem Biophys Res Commun. 2001;282:1161-1168. DOI: 10.1006/bbrc.2001.4705.

[62] Frati A, Antonini E, Ninfali P. Industrial Freezing, Cooking, and Storage Differently Affect Antioxidant Nutrients in Vegetables. Fruits, Vegetables, and Herbs. Cambridge: Academic Press; 2016. ISBN: 9780128029725. DOI: 10.1016/B978-0-12-802972-5.00002-0. 